\title{
Inclusion of kaolin in the diet of brown egg layers at the end of the production cycle
}

\author{
Túlio Leite Reis ${ }^{1^{*} \text { (D) Juan Carlos Palomino Quintero }}{ }^{2}$ (D) Felipe Dilelis ${ }^{1}$ (B) \\ Karoll Alfonso Torres Cordido ${ }^{3}$ (D) Edison José Fassani ${ }^{4}$ (i) Ligia Fátima Lima Calixto Li $^{1}$
}

${ }^{1}$ Universidade Federal Rural do Rio de Janeiro (UFRRJ), 23890-000, Seropédica, RJ, Brasil. E-mail: tulioreis@hotmail.com. *Corresponding author. ${ }^{2}$ Médico Veterinário e Zootecnista, Mestre em Zootecnia, Campos dos Goytacazes, RJ, Brasil.

${ }^{3}$ Universidade Estadual do Norte Fluminense Darcy Ribeiro (UENF), Campos dos Goytacazes, RJ, Brasil.

${ }^{4}$ Universidade Federal de Lavras (UFLA), Lavras, MG, Brasil.

ABSTRACT: This study investigated the inclusion of kaolin levels in the diet of brown egg layers at the end of the production cycle. A completely randomized design involved the distribution of 288 brown egg layers into six treatments of eight replications, with six birds per replication. When the birds reached the age of 63 weeks, the feeding of the experimental diets began. Diets differed by the inclusion of increasing levels of kaolin: Control (no additive), and the inclusion of 1\%, 2\%, 3\%, 4\%, and 5\% kaolin. The performance, egg quality, intestinal morphometry, and excreta moisture were evaluated. The inclusion of kaolin promoted improvement in the jejunum villus height, enabling less feed intake; however, there were no significant differences in egg quality. The excreta moisture decreased linearly as the kaolin level in the diet increased. The inclusion of 5\% kaolin in the diet of brown egg layers at the end of the production cycle improved intestinal morphometry and the quality of excreta through a reduction of moisture.

Key words: clay, egg production, egg shell quality, poultry nutrition.

Caulim na alimentação de poedeiras semipesadas ao final do ciclo produtivo

RESUMO: $O$ objetivo deste trabalho foi investigar a inclusão de niveis de caulim na dieta de poedeiras semipesadas ao final do ciclo de produção. Foram utilizadas 288 galinhas semipesadas distribuidas em delineamento inteiramente casualizado com seis tratamentos de oito repetições, contendo seis aves por repetição. Quando as aves atingiram a idade de 63 semanas, foi iniciada a alimentação com as dietas experimentais. As dietas diferiam entre si pela inclusão de níveis crescentes de caulim: controle (sem aditivo); e a inclusão de 1, 2, 3, 4 e 5\% de caulim na dieta. Foram avaliados o desempenho, a qualidade dos ovos, a morfologia intestinal e a umidade das excretas. A inclusão de caulim promoveu melhora na altura das vilosidades do jejuno, possibilitando menor consumo de ração. Não houve diferenças significativas para a qualidade dos ovos. A umidade das excretas diminuiu com o aumento do nível de caulim na dieta, respondendo de forma linear. A inclusão de caulim ao nível de $5 \%$ nas rações de poedeiras semipesadas ao final do ciclo de produção melhorou a morfometria intestinal e a qualidade dos excrementos por meio da redução de sua umidade.

Palavras-chave: argila, produção de ovos, qualidade da casca do ovo, nutrição avícola.

\section{INTRODUCTION}

The inclusion of clays as diet additives can affect the processes of digestion and nutrient absorption, promoting a longer feed retention time allowing for greater digestion and absorption, thereby influencing the performance of farm animals (SOUZA et al., 2019).

Among the clays of interest for use in animal nutrition is kaolin, which is not absorbed by the intestinal mucosa when ingested, but remains free in the lumen, protecting the epithelium. This protection occurs either by the formation of a colloid that covers the intestinal mucosa preventing both irritation and lesions, or by the binding of the kaolin to bacteria and toxins through the exchange of surface ions causing their elimination along with feces (BEDERSKAŁOJEWSKA \& PIESZKA, 2019). These characteristics are extremely important in situations where the presence of toxins and bacteria in the intestine can damage the epithelial walls, reducing villus height, thus causing poorer nutrient absorption rates, in addition to the high energy and nutritional expenditure required by the intestinal mucosa for its use.

One of the ways to control litter moisture is through the application of water-adsorbing substances 
to the feed, such as clays, which form a complex with water. The adsorbing capacity of these clays occurs due to their constitution in the form of an open molecule with predominant cations, which expands in the presence of water to several times its volume and allows water molecule adsorption. This fact allows the clay to form a colloid, improving the consistency of feces (AYDIN et al., 2020). However, this ability to adsorb molecules could cause the clay to interact with other feed ingredients with grow promoters additives, medications, and even some vitamins and minerals present in the diet, making these nutrients unavailable to the animal (GILANI et al., 2016).

Kaolin and other clays are widely used in several sectors of industry, including the production of medicines, which is possible because of their adsorption capacity and surface interactions. Compared to kaolin, other aluminosilicates have much larger surface areas and; therefore, greater binding potential, especially with cationic molecules (WILLIAMS \& HILLIER, 2014). Thus despite the potential for use in egg-laying poultry, the level of inclusion of clays in the diet of these birds has yet to be determined (GILANI et al., 2016).

Genetic improvements have prolonged the longevity of the current laying hen, creating complications at the end of the bird's productive life. According to SAFAMEHR et al. (2013) and REN et al. (2019), older layers have lower nutrient absorption rates, which can lead to decreased performance and lower egg quality. The shell quality is particularly affected, which is directly related to changes in hormonal dynamics and vitamin $\mathrm{D}$ production that alter the metabolism of calcium and phosphorus.

Therefore, this study tested the ability of kaolin in the diets of brown laying hens to minimize physiological wear at the end of the laying cycle, thus helping to maintain production performance, egg quality, intestinal morphometry, and excreta moisture.

\section{MATERIALS AND METHODS}

A total of 288 brown egg layers of the Dekalb Brown line were housed in the laying phase (14 weeks) in a pyramidal system of production cages, composed of nipple-type drinkers and trough-type feeders. The birds were distributed in a completely randomized design, with six treatments of eight replications, containing six birds per replication.

When the birds reached the age of 63 weeks, a supply of experimental feeds was introduced containing differing levels of kaolin. The additive was assigned by $\mathrm{CaO}$ of Brazil Ltd, and was composed of
$21.90 \% \mathrm{Al}_{2} \mathrm{O}_{2}, 62.80 \% \mathrm{SiO}_{2}, 1.40 \% \mathrm{Fe}_{2} \mathrm{O}_{3}$ and $0.40 \%$ $\mathrm{CaO}$. The treatments were the control (without the inclusion of the additive), and the inclusion of 1, 2, 3,4 and $5 \%$ of kaolin. The experimental diets were isoproteic and isoenergetic (Table 1) formulated on the basis of corn and soybean meal, meeting the levels established by ROSTAGNO et al. (2011).

After an adaptation period of 2 weeks, the collection of performance data began. The experimental period comprised five cycles of 28 days each. Throughout the laying phase, 17 hours of light per day were provided to the birds (natural light + artificial light).

\section{Analysis parameters}

The performance variables measured were egg yield per bird per day (in percentage), average egg weight (in grams), feed intake (in grams), feed conversion per mass (gram of feed consumed/gram of egg produced) and per dozen eggs produced (gram of feed consumed/dozen eggs produced), and viability of the birds (in percentage).

The egg quality analyses were performed at the end of each 28-day cycle, where 3 eggs/replication were collected for 2 consecutive days, totaling 48 eggs/treatment. The internal quality parameters of the eggs measured were the Haugh Unit calculation, yolk index, percentages of egg components, yolk pigmentation (made with the $\mathrm{DSM}^{\circledR}$ colorimetric fan, increasing pigmentation scale from 1 to 15 ), and the $\mathrm{pH}$ of the yolk and albumen. The external quality parameters of the eggs measured were shell thickness, specific gravity, and eggshell strength.

To evaluate the intestinal morphological characteristics, 48 brown egg layers (eight per treatment) aged 85 weeks were euthanized by cervical dislocation. The morphometry of the small intestine mucosa was measured by collecting $3 \mathrm{~cm}$ samples from the middle portion of each segment. Longitudinal slides were prepared, stapled in cardboard, washed with phosphate buffer solution (PBS pH 7.4), and fixed in $10 \%$ buffered formaldehyde ( $\mathrm{pH} 7.4$ ) for $48 \mathrm{~h}$. After this period, the samples were again washed with phosphate buffer solution (PBS pH 7.4) and stored in 70\% alcohol in a refrigerator while the histological slides were readied. The slides were prepared and the measurement was conducted using the Image $\mathrm{J}^{\circledR}$ program according to the methodology reported by TORRES-CORDIDO et al. (2013). The following measurements were taken for each segment of the small intestine (duodenum, jejunum, and ileum): villus height, crypt depth, and after determined these values, the villus/ crypt ratio, 
Table 1 - Composition of brown egg layers aged 65 to 85 weeks diets containing different levels of kaolin during the experimental period.

\begin{tabular}{|c|c|c|c|c|c|c|}
\hline Ingredients (\%) & 0 & 1 & 2 & 3 & 4 & 5 \\
\hline Corn $(7,88 \% \mathrm{~PB})$ & 66.615 & 64.481 & 62.362 & 60.243 & 58.228 & 56.008 \\
\hline Soybean meal ( $45 \% \mathrm{CP})$ & 21.470 & 21.883 & 22.280 & 22.675 & 22.947 & 23.465 \\
\hline Soybean oil & 0.854 & 1.578 & 2.297 & 3.017 & 3.706 & 4.455 \\
\hline Common salt & 0.445 & 0.446 & 0.447 & 0.448 & 0.449 & 0.449 \\
\hline Calcium limestone & 9.164 & 9.160 & 9.154 & 9.149 & 9.144 & 9.139 \\
\hline Dicalcium phosphate & 0.978 & 0.983 & 0.988 & 0.993 & 0.999 & 1.003 \\
\hline Vitamin supplement ${ }^{1}$ & 0.120 & 0.120 & 0.120 & 0.120 & 0.120 & 0.120 \\
\hline Mineral supplement ${ }^{2}$ & 0.120 & 0.120 & 0.120 & 0.120 & 0.120 & 0.120 \\
\hline DL-Methionine (99\%) & 0.175 & 0.177 & 0.180 & 0.183 & 0.187 & 0.189 \\
\hline L-Lysine HCL (78\%) & 0.007 & 0 & 0 & 0 & 0.047 & 0 \\
\hline L-Threonine & 0.005 & 0.005 & 0.005 & 0.005 & 0.006 & 0.005 \\
\hline Choline chloride $(60 \%)$ & 0.037 & 0.037 & 0.037 & 0.037 & 0.037 & 0.037 \\
\hline BHT & 0.010 & 0.010 & 0.010 & 0.010 & 0.010 & 0.010 \\
\hline Kaolin & 0 & 1 & 2 & 3 & 4 & 5 \\
\hline Total & 100 & 100 & 100 & 100 & 100 & 100 \\
\hline \multicolumn{7}{|c|}{ 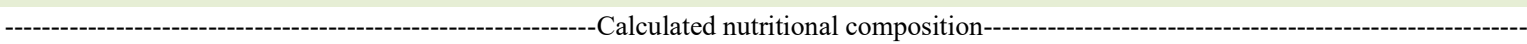 } \\
\hline Metabolizable energy (Mcal/Kg) & 2.850 & 2.850 & 2.850 & 2.850 & 2.850 & 2.850 \\
\hline Crude protein $(\%)$ & 15.6 & 15.6 & 15.6 & 15.6 & 15.6 & 15.6 \\
\hline Calcium $(\%)$ & 3.850 & 3.850 & 3.850 & 3.850 & 3.850 & 3.850 \\
\hline Available phosphorus (\%) & 0.275 & 0.275 & 0.275 & 0.275 & 0.275 & 0.275 \\
\hline Chlorine $(\%)$ & 0.300 & 0.300 & 0.300 & 0.299 & 0.299 & 0.298 \\
\hline Sodium $(\%)$ & 0.211 & 0.211 & 0.211 & 0.211 & 0.211 & 0.211 \\
\hline Potassium (\%) & 0.595 & 0.596 & 0.597 & 0.598 & 0.597 & 0.600 \\
\hline dig Lysine (\%) & 0.684 & 0.685 & 0.690 & 0.696 & 0.735 & 0.707 \\
\hline total Lysine $(\%)$ & 0.769 & 0.770 & 0.775 & 0.781 & 0.820 & 0.792 \\
\hline dig Met + Cist. (\%) & 0.628 & 0.628 & 0.629 & 0.629 & 0.630 & 0.630 \\
\hline total Met + Cist $(\%)$ & 0.692 & 0.692 & 0.692 & 0.692 & 0.692 & 0.692 \\
\hline dig Methionine (\%) & 0.403 & 0.404 & 0.406 & 0.408 & 0.411 & 0.412 \\
\hline total Methionine (\%) & 0.426 & 0.427 & 0.429 & 0.431 & 0.433 & 0.435 \\
\hline dig Threonine $(\%)$ & 0.524 & 0.524 & 0.525 & 0.525 & 0.526 & 0.526 \\
\hline total Threonine $(\%)$ & 0.607 & 0.607 & 0.607 & 0.607 & 0.607 & 0.607 \\
\hline
\end{tabular}

Composition per $\mathrm{kg}$ of the product ${ }^{1,2}:{ }^{1}$ Vitamin A (min) 7.500.000 UI/kg; vitamin D3 (min) 2.500.000 UI/kg; vitamin E (min) 1.200 $\mathrm{mg} / \mathrm{kg}$; vitamin $\mathrm{K} 3(\mathrm{~min}) 1.200 \mathrm{mg} / \mathrm{kg}$; thiamine $(\mathrm{min}) 1.500 \mathrm{mg} / \mathrm{kg}$; riboflavin (min) $5.500 \mathrm{mg} / \mathrm{kg}$; pyridoxine $(\mathrm{min}) 2000 \mathrm{mg} / \mathrm{kg}$; vitamin B12 (min) $12.000 \mathrm{mcg} / \mathrm{kg}$; niacin $35 \mathrm{~g} / \mathrm{kg}$; calcium pantothenate (min) $10 \mathrm{~g} / \mathrm{kg}$; biotin (min) $67 \mathrm{mg} / \mathrm{kg} ;{ }^{2} \mathrm{Iron}(\mathrm{min}) 60 \mathrm{~g} / \mathrm{kg}$; copper (min) $13 \mathrm{~g} / \mathrm{kg}$; manganese (min) $120 \mathrm{~g} / \mathrm{kg}$; zinc (min) $100 \mathrm{~g} / \mathrm{kg}$; iodine (min) $2.500 \mathrm{mg} / \mathrm{kg}$; selenium (min) $500 \mathrm{mg} / \mathrm{kg}$.

which is the ratio between the height of a villus and the depth of the crypt of the same villus.

At the end of the experimental period, a new distribution of birds was placed in the cages to determine the moisture of the excreta. The new design consisted of the same six treatments $(0 \%, 1 \%, 2 \%$, $3 \%, 4 \%$, and $5 \%$ inclusion of kaolin in the feed), with six replications of four hens per replication. After five days of adaptation, one plastic-enveloped tray was placed under each cage for the total collection of excreta, which occurred twice a day in the morning and afternoon at different times for three consecutive days (SAKOMURA \& ROSTAGNO, 2016). The excreta from each cage were weighed immediately after each collection, placed in properly labeled plastic bags, and stored in a freezer $\left(-10^{\circ} \mathrm{C}\right)$ for further analysis. The samples were thawed, weighed, and homogenized, and $250 \mathrm{~g}$ sub-samples were pre-dried in a ventilated oven at $55{ }^{\circ} \mathrm{C}$ for 72 hours. After this procedure, the excreta were weighed to obtain the dry 
matter of the samples, and the difference between this value and the initial weight of the excreta (percentage) was considered the moisture content (AOAC, 1990).

\section{Statistical analyses}

The results were subjected to analysis of variance using the BioEstat ${ }^{\mathbb{R}}$ Program. The effects of the levels of kaolin were estimated through analysis of variables by the linear and quadratic regression models at a significance level of 5\%, according to the best adjustment obtained for each variable, based on the highest value of coefficient of determination for the choice of the model.

\section{RESULTS AND DISCUSSION}

The percentage of egg laying was not influenced by the inclusion of kaolin (Table 2). These results contrasted with those reported by KIM et al. (2011) which showed that using lower kaolin levels in the diets of 58-week-old laying hens $(0 \%-0.6 \%$ of the additive), caused an increase in egg yield of $0.2 \%$. The laying rate observed in this experiment related to the average laying advocated by the line management guide (HENDRIX GENETICS, 2016), regardless of the inclusion of kaolin. Feed conversion per dozen eggs produced and viability of rearing were not affected $(\mathrm{P}>0.05)$ by kaolin.

A quadratic improvement in feed conversion per mass was determined $(\mathrm{P}<0.05)$, and by unfolding the equation, the optimal inclusion level of kaolin of $4.378 \%$ in the feed was used to estimate better feed conversion rate. The feed intake decreased linearly $(\mathrm{P}$ $<0.05$ ) with the inclusion of kaolin levels in the feed.

This result is related to the ability of clays to improve intestinal health and thus providing better integrity of the epithelium, as occurred with the jejunum villi in the intestine of the hens in the present study (Table 4). Similar results were reported by SCHNEIDER et al. (2017), who stated that the inclusion of clay promotes benefits in intestinal morphology and improvements in the digestive system and enzymatic activity, such as that of chymotrypsin, trypsin, and amylase in the small intestine.

The gastrointestinal tract naturally requires a large supply of nutrients for its maintenance and cell renewal, and during an infection, pathogenic microorganisms degrade the mucosa, further increasing the amount of nutrients necessary for its repair; a damaged epithelium also reduces nutrient absorption effectiveness (SCHNEIDER et al., 2017). In addition, with advancing age, layers exhibit a lower absorption rate of some nutrients mainly because of lower enzyme secretion and lower speed of replacement of intestinal mucosa cells; therefore, older hens require a diet consisting of nutrients that are easier to absorb or are more easily degraded. The nutritional requirement of the bird, as well as its level of consumption, is defined by the amount of nutrients necessary for maintenance (basal metabolic activity) and production. In this context, the role of kaolin is highlighted when considering the various factors that affect the bird's requirement for nutrients, particularly in terms of intestinal health. When good intestinal health is maintained, the nutritional requirement is less; therefore, a lower supply of nutrients reflects less consumption. Concomitantly with the presence of kaolin, the nutrients present in the diet will be better utilized, either by the higher absorptive rates induced by the greater integrity of the villi, or by the ability of the clay to increase the enzymatic activity of gastrointestinal secretion by increasing the digestion of the substrate (SOUZA et al., 2019; AYDIN et al., 2020). KIM et al. (2011), also observed a reduction

Table 2 - Performance of brown egg layers aged 65 to 85 weeks fed different levels of kaolin in the diet.

\begin{tabular}{|c|c|c|c|c|c|c|c|c|}
\hline & 0 & 1 & 2 & 3 & 4 & 5 & Regression & $\mathrm{CV}$ \\
\hline FI (kg) & 0.117 & 0.120 & 0.117 & 0.115 & 0.116 & 0.114 & $\mathrm{~L}^{*}$ & 2.74 \\
\hline Lay (\%) & 92.80 & 94.28 & 93.36 & 94.53 & 92.36 & 92.73 & NS & 2.16 \\
\hline $\mathrm{FC} /$ mass & 2.045 & 1.998 & 2.012 & 1.948 & 1.978 & 1.959 & $Q^{* *}$ & 2.74 \\
\hline $\mathrm{FC} / \mathrm{dz}$ & 1.524 & 1.511 & 1.509 & 1.463 & 1.527 & 1.515 & NS & 3.34 \\
\hline Viab (\%) & 100 & 100 & 100 & 100 & 100 & 100 & NS & - \\
\hline
\end{tabular}

FI: Feed intake; Lay: laying percentage; FC/mass: feed conversion per mass; FC/dz: feed conversion per dozen eggs; Viab: viability. $\mathrm{NS}=$ non-significant; $\mathrm{CV}=$ coefficient of variation; $\mathrm{L}^{*}=$ Linear regression, Equation: $\mathrm{Y}=0.1194-0.0008 \mathrm{X}, \mathrm{p}=0.0165 ; \mathrm{Q}^{* *}=$ Quadratic regression, Equation: $\mathrm{Y}=2.0421-0.0344 \mathrm{X}+0.0037 \mathrm{X}^{2}, \mathrm{p}=0.018$. 
of the feed intake with a quadratic effect in laying hens in feed conversion, although with a much lower kaolin content $(0.2 \%$ of inclusion in the feed) than those used in the present study. OWEN et al. (2012), working with broiler chickens, included between $0 \%$ and $4 \%$ of kaolin in the diets, and reported better feed conversion for birds that consumed $1 \%$ and $4 \%$ of clay compared to both the control (no kaolin) and birds that consumed feed containing 3\% kaolin. That study also observed increased feed intake of the chickens that were not given kaolin in the diet compared to the others, regardless of the level of clay given. The use of clays in animal nutrition presents different results on performance, and these results may be affected by clay type and composition, particle size, and physicochemical and structural characteristics.

The kaolin levels tested did not significantly $(\mathrm{P}>0.05)$ influence the internal and external quality parameters of the eggs (Table 3). Egg weights were close to the expected weight and the Haugh unit was superior to that normally reported for laying hens at this age (HENDRIX GENETICS, 2016).

The weight percentage of the egg components (egg yolk, albumen, and shell) is directly influenced by the age of the bird, and their modification includes more challenging nutritional strategies, since as the hen ages, the incidence of follicular atresia increases and follicle recruitment decreases, as they mature more slowly and ovulate with larger size when compared to young birds (SAH
\& MISHRA, 2018), causing an increase in the size of the yolk in these eggs. The $\mathrm{pH}$ of albumen and yolk in fresh eggs also generally has little variation with the use of nutritional strategies, only becoming more alkaline as the egg is stored.

There was no significant difference for yolk color $(\mathrm{P}>0.05)$. The nutrient requirement used for formulating the experimental diets was the same, containing the same amounts of vitamins and natural pigments in the ingredients. The color of the yolk is related to the presence in the diet of these synthetic and natural pigments and vitamins. The presence of clays in diets can generate complexes with these nutrients, preventing their absorption, thus producing lighter yolks, a fact not observed in the present study. These results disagree with those reported by GILANI et al. (2013) who found reduced yolk pigmentation when bentonites were included in up to $2 \%$ of the light-layer feed at 51 weeks of age.

All shell measurement parameters indicated a good quality for this structure; however, the use of kaolin in the present study was tested in older layers and; therefore, it was expected that this clay had some effect in increasing intestinal calcium absorption due to high cation exchange capacity (SCHNEIDER et al., 2017), reflecting an improvement in the thickness of the shell, but this was not observed here $(\mathrm{P}>0.05)$. The metabolism of $\mathrm{Ca}$ and $\mathrm{P}$ is highly complex and depends on several dietary, physiological, and hormonal factors (SAFAMEHR et al. 2013; REN et al., 2019).

Table 3 - Quality of eggs of brown egg layers aged 65 to 85 weeks fed different levels of Kaolin in the diet.

\begin{tabular}{|c|c|c|c|c|c|c|c|c|}
\hline & 0 & 1 & 2 & 3 & 4 & 5 & Regression & $\mathrm{CV}$ \\
\hline EW (g) & 61.90 & 63.49 & 62.69 & 62.43 & 63.91 & 63.24 & NS & 2.33 \\
\hline YI & 0.43 & 0.44 & 0.43 & 0.43 & 0.43 & 0.43 & NS & 2.14 \\
\hline Color & 7.88 & 7.87 & 7.77 & 7.79 & 7.83 & 7.75 & NS & 8.58 \\
\hline UH & 97.84 & 96.98 & 97.89 & 98.65 & 95.91 & 96.10 & NS & 3.21 \\
\hline Yolk (\%) & 26.18 & 26.49 & 26.49 & 26.03 & 26.09 & 26.09 & NS & 2.93 \\
\hline Alb (\%) & 64.39 & 63.79 & 63.75 & 64.22 & 64.28 & 64.12 & NS & 0.92 \\
\hline Shell (\%) & 9.43 & 9.59 & 9.53 & 9.65 & 9.53 & 9.56 & NS & 3.02 \\
\hline Alb pH & 8.10 & 7.94 & 7.92 & 7.95 & 8.01 & 8.07 & NS & 3.84 \\
\hline Yolk pH & 6.23 & 6.07 & 6.15 & 6.07 & 6.11 & 6.08 & NS & 4.04 \\
\hline $\mathrm{ST}(\mathrm{mm})$ & 0.39 & 0.39 & 0.39 & 0.39 & 0.39 & 0.39 & NS & 3.55 \\
\hline SG & 1.087 & 1.0875 & 1.089 & 1.0885 & 1.089 & 1.09 & NS & 5.5 \\
\hline ES (kgf) & 4.022 & 4.078 & 4.194 & 4.204 & 3.988 & 4.214 & NS & 18.825 \\
\hline
\end{tabular}

EW: egg weight; YI: yolk index; Color: yolk pigmentation; Haugh Unit: HU; Yolk (\%): yolk percentage; Alb (\%): albumen percentage; Shell (\%): shell percentage; Alb pH: albumen pH; ST: shell thickness; SG: specific gravity and ES: eggshell strength. 
KIM et al. (2011) studying the inclusion of kaolin in diets for brown egg layers aged 30 to 58 weeks, also reported no significant differences for shell strength, weight, or thickness, or egg weight, egg yolk color, height, weight, albumen height, or Haugh unit, similar to the present study. GILANI et al. (2013) providing bentonite in the diet, also did not find differences in egg weight, specific gravity, thickness, or shell percentage.

PRASAI et al. (2018) reported no significant differences in shell weight and thickness, Haugh units, or eggshell strength when supplementing hen diets with zeolites and bentonites, despite their inclusion promoting higher weight of the quail eggs, when supplied up to the level of $4 \%$.

The intestinal morphometry evaluated by villus height in the duodenum and ileum of hens (Table 4) was not influenced $(P>0.05)$ by the inclusion of kaolin. However, greater inclusions of this clay increased the height of the jejunum villi linearly ( $\mathrm{P}$ $<0.05)$. There is a high positive correlation between villus size and nutrient absorption rates.

PRASAI et al. (2018) found increased villus size and crypt depth in the three segments of the small intestine of brown egg layers by including zeolites and bentonites in the diet. CHEN et al. (2020) did not find significant differences for villi size, crypt depth, and villus/crypt ratio of duodenum, jejunum, and ileum in layers fed diets containing montmorillonite.
The linear improvement in intestinal quality with the inclusion of kaolin can be explained by the fact that kaolin is not absorbed by the intestinal mucosa, being free in the lumen, thus protecting the epithelium by forming a mucosa-covered colloid. Another mechanism of clays relates to their ability to bind to bacteria and toxins by means of the exchange of surface ions, causing them to be eliminated along with feces (BEDERSKAŁOJEWSKA \& PIESZKA, 2019). These properties prevent lesions that cause villus size reduction.

Crypt depth and villus/crypt ratio in the duodenum, jejunum, and ileum of the hens were not influenced by the inclusion of the tested clay $(\mathrm{P}>0.05)$. YALÇIN et al. (2017) providing sepiolite in broiler diets, also only found larger villus size in one of the small intestine (duodenum) segments, and reported no significant differences for crypt depth and villus/ crypt ratio in any of the portions. LEMOS et al. (2015) including kaolin in the broiler diets up to $1.5 \%$, and did not find significant differences for crypt depth in the duodenum; however, they observed a larger villus size, a fact that reflected positively on feed intake and conversion.

The excreta moisture behaved linearly $(\mathrm{P}$ $<0.05$ ) to the inclusion of kaolin in the diet, so that as the kaolin level increased, less excreta moisture occurred (Table 5). LEMOS et al. (2015) including up to $1.5 \%$ kaolin in broiler diets and SOUZA et al. (2019) with $4.5 \%$ kaolin for laying quails also observed a linear reduction in excreta moisture. This

Table 4 - Intestinal morphometry of the different intestinal segments of 85-week-old brown egg layers fed different levels of kaolin in the diet.

\begin{tabular}{|c|c|c|c|c|c|c|c|c|}
\hline & 0 & 1 & 2 & 3 & 4 & 5 & Regression & $\mathrm{CV}$ \\
\hline \multicolumn{9}{|c|}{ } \\
\hline Villus & 1273.9 & 1277.9 & 1452.7 & 1.337 .2 & 1363.1 & 1323.0 & NS & 9.49 \\
\hline Crypt & 181.0 & 159.2 & 183.8 & 155.7 & 179.8 & 152.5 & NS & 24.46 \\
\hline Villus/crypt & 7.24 & 8.52 & 8.32 & 8.90 & 7.13 & 8.72 & NS & 25.25 \\
\hline \multicolumn{9}{|c|}{ - } \\
\hline Villus & 1033.7 & 1041.7 & 1020.4 & 1125.3 & 1046.8 & 1193.3 & $\mathrm{~L}^{*}$ & 10.87 \\
\hline Crypt & 141.0 & 196.0 & 136.6 & 143.1 & 125.3 & 159.9 & NS & 14.60 \\
\hline Villus/crypt & 7.40 & 5.54 & 8.42 & 7.38 & 7.60 & 6.40 & NS & 17.75 \\
\hline \multicolumn{9}{|c|}{ - } \\
\hline Villus & 638.8 & 674.2 & 642.5 & 622.9 & 693.6 & 629.9 & NS & 18.30 \\
\hline Crypt & 108.4 & 99.7 & 99.9 & 95.1 & 115.6 & 108.3 & NS & 25.08 \\
\hline Villus/crypt & 6.31 & 6.04 & 7.44 & 7.92 & 5.94 & 6.63 & NS & 16.95 \\
\hline
\end{tabular}

Villus: villus height; Crypt: crypt depth; Villus/crypt: villus crypt ratio.

$\mathrm{NS}=$ on-significant $\mathrm{CV}=$ coefficient of variation; $\mathrm{L}^{*}=$ Linear regression, Equation: $\mathrm{Y}=1,015.41+226.11 \mathrm{X}, \mathrm{p}=0.0297$ 
Table 5 - Moisture of the excreta from 85-week-old brown egg layers fed different kaolin levels in the diet.

\begin{tabular}{|c|c|c|c|c|c|c|c|c|}
\hline & 0 & 1 & 2 & 3 & 4 & 5 & Regression & $\mathrm{CV}$ \\
\hline Moisture (\%) & 79.15 & 79.38 & 76.45 & 75.10 & 74.99 & 73.87 & $\mathrm{~L}^{*}$ & 3.17 \\
\hline
\end{tabular}

$\mathrm{CV}=$ coefficient of variation; $\mathrm{L}^{*}=$ Linear regression, Equation: $\mathrm{Y}=79.4144+1.1697 \mathrm{X}, \mathrm{p}<0.0001$.

is because owing to the ability to expand their layers and the presence of cations in their structure, the clays can absorb large amounts of water, resulting in the formation of more consistent excreta (AYDIN et al., 2020). In addition to the property of colloid formation, clays can promote antidiarrheal action by improving the quality of excreta through their ability to adsorb bacteria and toxins, which cause lesions and consequently greater fluidity in the intestinal content (BEDERSKA-ŁOJEWSKA \& PIESZKA et al., 2019).

Contrary results were found by YALÇIN et al. (2017), who reported three levels of sepiolite $(0 \%, 1 \%$ and $2 \%)$ in broiler diets but did not find significant differences in litter moisture.

\section{CONCLUSION}

The use of kaolin in the diet of brown egg layers at the end of the production cycle demonstrated zootechnical viability, represented by high production rates, excellent egg quality, and reduced excreta moisture.

This clay demonstrated the ability to minimize the physiological wear and tear borne by birds in the final stage of production because of the prolongation of the intensity and persistence of the laying, marked characteristics due to the genetic improvements in the current layer longevity.

\section{ACKNOWLEDGEMENTS}

The company $\mathrm{CaO}$ do Brasil Ltda. for providing the tested ingredient and financial support for this Project, and was financed in part by the Coordenação de Aperfeiçoamento de Pessoal de Nível Superior (CAPES), Brasil - Finance code 001.

\section{BIOETHICS AND \\ COMMITTEE APPROVAL \\ BIOSECURITY}

This study was approved by the Ethics Committee on the Use of Animals in Scientific Experiences (CEUA / UFRRJ / IZ) under process number: 23083.005984/2017-02.

\section{DECLARATION OF CONFLICT OF INTEREST}

The authors declare no conflict of interest. The founding sponsors had no role in the design of the study; in the collection, analyses, or interpretation of data; in the writing of the manuscript, and in the decision to publish the results.

\section{AUTHORS' CONTRIBUTIONS}

All authors contributed equally to the conception and writing of the manuscript. All authors critically revised the manuscript and approved the final version.

\section{REFERENCES}

AOAC. Official methods of analysis of AOAC International. 15th ed. Washington, D.C., 1990.

AYDIN, Ö. D. et al. The use of glauconite as a feed additive in broiler nutrition and its effect on growth performance, intestinal histomorphology and biomechanical properties of bones. Kafkas Üniversitesi Veteriner Fakültesi Dergisi, v.26, n.3, 2020. Available from: <http://vetdergikafkas.org/uploads/ pdf/pdf_KVFD_2682.pdf $>$ Accessed: Jan. 25, 2021. doi: 10.9775/ kvfd.2019.23154

BEDERSKA-ŁOJEWSKA, D.; PIESZKA, M. Dietary kaolin clay in pre- and post-weaned piglets and its influence on haematological and biochemical parameters, and intestinal microflora status. Annals of Animal Science, v.19, n.4, p.1021-1034, 2019. Available from: $<$ https://content.sciendo.com/view/journals/aoas/19/4/article-p1021. xml>. Accessed: Jan. 25, 2021. doi: 10.2478/aoas-2019-0031.

CHEN, J. F. et al. The effects and combinational effects of Bacillus subtilis and montmorillonite on the intestinal health status in laying hens. Poultry Science, v.99, n.3, p.1311-1319, 2020. Available from: <https://www.sciencedirect.com/science/article/pii/ S0032579119578130>. Accessed: Aug. 24, 2020. doi: 10.1016/j. psj.2019.11.016.

GILANI, A. H. et al. Impact of sodium bentonite addition to the diets containing cottonseed meal on productive traits of HY-line W-36 hens. The Journal of Animal \& Plant Sciences, v. 23, p. 411-415, 2013. Available from: < https://pdfs.semanticscholar.org/ b4b9/c7d1876c73a826695a0f57261d88e6337306.pdf.> Accessed: Aug. 18, 2020. 
GILANI, A. et al. Appraisal of the impact of aluminosilicate use on the health and performance of poultry. Turkish Journal of Veterinary and Animal Sciences, v. 40, n. 3, p. 255-262, 2016. Available from: $<$ https://journals.tubitak.gov.tr/veterinary/abstract.htm?id=18492> Accessed: Feb. 09, 2021. doi:10.3906/vet-1501-103.

HENDRIX GENETICS. Dekalb Brown Product Guide - Cage Production System. Netherlands: ISA, 2016. Available from: $<$ https://www.dekalb-poultry.com/documents/576/Dekalb Brown_CS_cage_English_guide.pdf $>$. Accessed: Feb. 09, 2021.

KIM, J. S. et al. Effects of Kaolin (Natural Ligneous Clay) Supplementation on Performance and Egg Quality in Laying Hens. Journal of Animal Science and Technology, v.53, n.2, p.133138, 2011. Available from: <http://www.koreascience.kr/article/ JAKO201115952330758.page>. Accessed: Aug. 18, 2020. doi: 10.5187/JAST.2011.53.2.133.

LEMOS, M. J. D. et al. Kaolin in the diet and its effects on performance, litter moisture and intestinal morphology of broiler chickens. Ciência Rural, v.45, n.10, p.1835-1840, 2015 Available from: $<$ https://www.scielo.br/scielo.php?pid=S010384782015001001835\&script $=$ sci_arttext $>$. Accessed: Aug. 18, 2020. doi: 10.1590/0103-8478cr20141193.

OWEN, O. J. et al. The effects of dietary kaolin (clay) as feed additive on the growth performance of broiler chickens. Greener Journal of Agricultural Sciences, v.2, n.6, p.233236, 2012. Available from: <https:/www.researchgate.net/ publication/320075936_The_Effects_of_Dietary_Kaolin_Clay_ as_Feed_Additive_on the_Growth_Performance_of Broiler Chickens>. Accessed: Aug. 18, 2020.

PRASAI, T. P. et al. Effect of biochar, zeolite and bentonite feed supplements on egg yield and excreta attributes. Animal Production Science, v.58, n.9, p.1632-1641, 2018. Available from: $<$ https://www.publish.csiro.au/an/an16290>. Accessed: Aug. 18, 2020. doi: 10.1071/AN16290.

REN,Z. et al. Dynamics of serum phosphorus, calcium, and hormones during egg laying cycle in Hy-Line Brown laying hens. Poultry Science, v.98, n.5, 2193-2200, 2019. Available from: <https:// www.sciencedirect.com/science/article/pii/S0032579119300707>. Accessed: Jan. 25, 2021. doi: 10.3382/ps/pey572.

ROSTAGNO, H. S., L. F. T. et al. Tabelas brasileiras para aves e suínos: Composição dos alimentos e exigências nutricionais. Viçosa: UFV, 2011. 3v.
SAFAMEHR, A. et al. The effects of dietary calcium sources and vitamin D3 on egg quality and performance in laying hens. Iranian Journal of Applied Animal Science, v.3, n.1, 167-175 2013. Available from: <https:/www.sid.ir/en/ journal/ViewPaper.aspx?id=324030 $>$. Accessed: Jan. 25, 2021

SAH, N.; MISHRA, B. Regulation of egg formation in the oviduct of laying hen. World's Poultry Science Journal, v.74, n.3, p.509522, 2018. Available from: <https://www.tandfonline.com/doi/ abs/10.1017/S0043933918000442>. Accessed: Jan. 25, 2021. doi: $10.1017 / \mathrm{S} 0043933918000442$

SAKOMURA N. K.; ROSTAGNO, H. S. Métodos de pesquisa em nutrição de monogástricos. 2 ed. Funep Press: UNESP, SP. 2016.

SCHNEIDER, A. F. et al. Zeolites in poultry and swine production. Ciência Rural, v.47, n.8, 2017. Available from: $\quad<$ https://www.scielo.br/scielo.php?pid=S010384782017000800652 \&script $=$ sci_arttext $>$. Accessed: Aug. 24, 2020. doi: 10.1590/0103-8478cr20160344.

SOUZA, D. S. et al. Inclusion of kaolin in the feed of Japanese quails during the production phase. Revista Colombiana de Ciencias Pecuarias, v.32, n.4, 2019. Available from: <https://revistas.udea.edu.co/index.php/ rccp/article/view/338405>. Accessed: Jan. 25, 2021. doi: 10.17533/udea.rccp.v32n4a03.

TORRES-CORDIDO, K. A. A. et al. Effects of corn replacement by sorghum in broiler diets on performance and intestinal mucosa integrity. Poultry Science, v.92, n.6, p.1564-1571, 2013. Available from: $\quad<$ https://www.sciencedirect.com/science/article/pii/ S0032579119387504>. Accessed: Aug. 18, 2020. doi: 10.3382/ ps.2012-02422.

WILLIAMS, L. B.; HILLIER, S. Kaolins and health: from first grade to first aid. Elements, v.10, n.3, p.207-211, 2014. Available from: $\quad<$ https://asu.pure.elsevier.com/en/publications/fromfirst-grade-to-first-aid $>$. Accessed: Feb. 09, 2021. doi: 10.2113/ gselements.10.3.207.

YALÇIN, S. et al. Sepiolite as a feed supplement for broilers. Applied Clay Science, v.148, p.95-102,2017. Available from: $\quad<$ https://www.sciencedirect.com/science/article/abs/pii/ S0169131717303587>. Accessed: Aug. 18, 2020. doi: 10.1016/j. clay.2017.08.007. 